\title{
Measures of Emergency Department Crowding, a Systematic Review. How to Make Sense of a Long List
}

\author{
Samer Badr (D) ${ }^{1,2}$ \\ Andrew Nyce 3,4 \\ Taha Awan 5 \\ Dennise Cortes ${ }^{5}$ \\ Cyrus Mowdawalla ${ }^{5}$ \\ Jean-Sebastien Rachoin 1,2,6 \\ 'Division of Hospital Medicine, Cooper \\ University Health Care, Camden, NJ, \\ USA; ${ }^{2}$ Department of Medicine, Cooper \\ Medical School of Rowan University, \\ Camden, NJ, USA; ${ }^{3}$ Department of \\ Emergency Medicine, Cooper University \\ Health Care, Camden, NJ, USA; \\ ${ }^{4}$ Department of Emergency Medicine, \\ Cooper Medical School of Rowan \\ University, Camden, NJ, USA; \\ ${ }^{5}$ Department of Medical Education, \\ Cooper Medical School of Rowan \\ University, Camden, NJ, USA; ${ }^{6}$ Division \\ of Critical Care, Cooper University \\ Health Care, Camden, NJ, USA
}

\begin{abstract}
Emergency department (ED) crowding, a common and serious phenomenon in many countries, lacks standardized definition and measurement methods. This systematic review critically analyzes the most commonly studied ED crowding measures. We followed the Preferred Reporting Items for Systematic Review and Meta-analysis (PRISMA) guidelines. We searched PubMed/Medline Database for all studies published in English from January 1st, 1990, until December 1st, 2020. We used the National Institute of Health (NIH) Quality Assessment Tool to grade the included studies. The initial search yielded 2293 titles and abstracts, of whom we thoroughly reviewed 109 studies, then, after adding seven additional, included 90 in the final analysis. We excluded simple surveys, reviews, opinions, case reports, and letters to the editors. We included relevant papers published in English from 1990 to 2020 . We did not grade any study as poor and graded 18 as fair and 72 as good. Most studies were conducted in the USA. The most studied crowding measures were the ED occupancy, the ED length of stay, and the ED volume. The most heterogeneous crowding measures were the boarding time and number of boarders. Except for the National ED Overcrowding Scale (NEDOCS) and the Emergency Department Work Index (EDWIN) scores, the studied measures are easy to calculate and communicate. Quality of care was the most studied outcome. The EDWIN and NEDOCS had no studies with the outcome mortality. The ED length of stay had no studies with the outcome perception of care. ED crowding was often associated with worse outcomes: higher mortality in $45 \%$ of the studies, worse quality of care in $75 \%$, and a worse perception of care in $100 \%$. The ED occupancy, ED volume, and ED length of stay are easy to measure, calculate and communicate, are homogenous in their definition, and were the most studied measures.
\end{abstract}

Keywords: overcrowding, waiting room, boarding, occupancy, volume, length of stay

\section{Introduction}

Emergency Department (ED) crowding is a common problem in the USA and around the world. Crowding can lead to the boarding of admitted patients in the ED. In a recently revised policy statement, the American College of Emergency Physicians lists several resulting problems. These include treating patients in areas not designated for treatment, such as hallways, treating boarded patients by ED nurses, increased ambulance diversion time, and decreased patient and ED staff satisfaction. ${ }^{1}$ Most authorities agree that ED crowding is a public health crisis that negatively impacts patient safety, worsens the quality of care, and increases mortality in some cases. ${ }^{2}$
Correspondence: Samer Badr Division of Hospital Medicine, Cooper University Health Care, One Cooper Plaza, Dorrance Suite 222, Camden, NJ, 08103, USA

$\mathrm{Tel}+\mid$ 856-342-3150

Fax $+\mid$ 856-968-84|8

Email badr-samer@cooperhealth.edu 
Many EDs have in the last decade seen an increase in the number and acuity of illness of their patients. ${ }^{3}$ As the population ages, ED crowding is likely to continue to worsen. Furthermore, in some instances, the ED houses an observation unit for specific diseases or diagnoses, a process that can itself worsen crowding.

Accurate ED crowding measurement and evidencebased understanding of its impact are prerequisites before attempting to find solutions. At its core, crowding depends on three variables: the volume of patients arriving (input), the time to process and, or treat patients (throughput), and the volume of patients leaving the ED (output). Any combination involving a rise in input, a delayed throughput, or a decreased output can lead to crowding.

Despite substantial published research, there is still no consensus around the best metric to measure and define ED crowding. With the lack of standardized measuring methods, the comparison of research paper results cannot always generalize their applicability. This review of ED crowding measures literature attempts to provide a comparison of the different measures.

\section{Methods Study Design}

A comprehensive systematic review of published medical literature from 1990 to 2020 revealed multiple ED crowding definitions. We focused on eight measures that were both commonly accepted and not specific to a country's health system:

1. ED occupancy: The proportion of occupied ED beds, which is the number of occupied beds divided by the total number of ED beds, usually expressed in percentage.

2. ED length of stay (LOS): The time patients spend in the ED.

3. ED Volume: The total number of patients in the ED during a defined time.

4. ED boarding time: The time admitted patients spend in the ED waiting for transport to their assigned hospital bed.

5. Number of boarders: The number of patients waiting in the ED for a hospital bed.

6. Waiting room number: The number of patients in the waiting room of an ED.

7. The National ED Overcrowding Scale (NEDOCS) measure: A score based on a formula that requires the following variables: the number of ED patients, the number of ED beds, the number of hospital beds, the number of ventilators in use in the ED, the waiting time for the longest admission, the waiting room time of the last patient called to a bed, and the number of admits in the ED.

8. The Emergency Department Work Index (EDWIN) score: Is based on a formula that aims to measure the ratio of workload to work capacity. The formula is $\sum \mathrm{n}_{\mathrm{i}} \mathrm{t}_{\mathrm{i}} / \mathrm{N}_{\mathrm{a}}\left(\mathrm{B}_{\mathrm{T}}-\mathrm{B}_{\mathrm{A}}\right)$, where $\mathrm{n}_{\mathrm{i}}$ is the number of patients in the ED in triage category $i, t_{i}$ is triage category, $N_{a}$ is the number of attending physicians on duty, $\mathrm{B}_{\mathrm{T}}$ is the number of treatment bays, and $\mathrm{B}_{\mathrm{A}}$ is the number of admitted patients in the ED. The triage category is defined by the Emergency Severity Index (ESI).

The outcomes studied in the literature belonged to one of these three categories: mortality, quality of care, and perception of care. The quality-of-care outcome includes the timeliness of care. It often involves meeting pre-specified core measures, administering appropriate tests or medications in a timely fashion, or avoiding negative throughput events such as having patients leave without treatment (LWOT) or going on ambulance diversion. The perception of care outcome reflects the physicians' and nurses' impressions of the state of ED crowding.

This systematic review follows the Preferred Reporting Items for Systematic Review and Meta-analysis (PRISMA) checklist for reporting. This study was exempt from IRB approval.

\section{Search Strategy and Study Selection}

On December 15th, 2020, three independent reviewers (CM, DC, TA) queried the PubMed (Medline) database with the keywords "ED, ER, Emergency Room, Emergency Department" and "Crowding, Overcrowding" analyzing titles and abstracts of all the articles published in English from January 1st, 1990 until December 1st, 2020. Our senior author (JSR) performed an initial review to guide the selection and inclusion of the crowding measures and outcomes. This search was not shared with the three other independent reviewers to avoid bias.

After reading the full text, the reviewers decided on the manuscripts meeting the inclusion criteria for the final analysis. The senior author (JSR) resolved disagreements. The reviewers included all types of studies (retrospective, prospective, qualitative, quantitative) and excluded simple surveys, review papers, opinions, letters to the editors, and case 
reports. They also included, when appropriate, additional studies found in the bibliographies of the manuscripts, using the same review process. In terms of content, the included studies needed to be relevant to the subject, with clear studied outcomes and measures of crowding.

The three independent reviewers (CM, DC, TA) manually extracted data into a standardized table provided by the senior author (JSR). The table's categories are the date of publication, country of the studied population, type of study, population studied, ED crowding variable, outcome measured, type of hospitals, diagnoses, and type of patients (adult/pediatric/all).

Two independent reviewers (SB and either CM, DC, or TA) graded each of the manuscripts included in the final analysis using the National Institute of Health (NIH) Study Quality Assessment Tool. ${ }^{4}$ The possible grades based on the tool are Good, Fair, and Poor. The senior author (JSR) reviewed the ratings if the grading was not concurrent and weighed in. The authors had decided to eliminate papers they would grade as having a Poor Quality.

\section{Results}

The initial search yielded 2293 abstracts, 2184 of whom got excluded after title and abstract review. The bibliography search of the resulting 109 manuscripts yielded seven additional studies. Twenty-six of the 116 studies were later excluded after full review for the following reasons: ED crowding measures inclusion criteria not met (6 studies), selected outcome measures criteria not met (14), simple survey (5), incorrect time frame (1) (Figure 1). The final analysis, therefore, included 90 studies.

\section{Study Characteristics}

None of the chosen 90 papers got eliminated due to a grade of "Poor" based on the NIH tool. The reviewers graded most (72) of the selected studies "Good" with 18 studies graded as "Fair." The studies mainly occurred after the year 2000. The majority of the studies occurred in the USA (55 out of 90 studies), followed by Canada (7 out of 90) and South Korea (4 out of 90). The studies were all observational, mostly retrospective cohorts. The majority of the studies were performed in tertiary care centers. We list details about each of the 90 studies in the Supplementary Table 1; we include the year and country of the study, the type of study, the population studied, the crowding measure and outcome each study addresses,

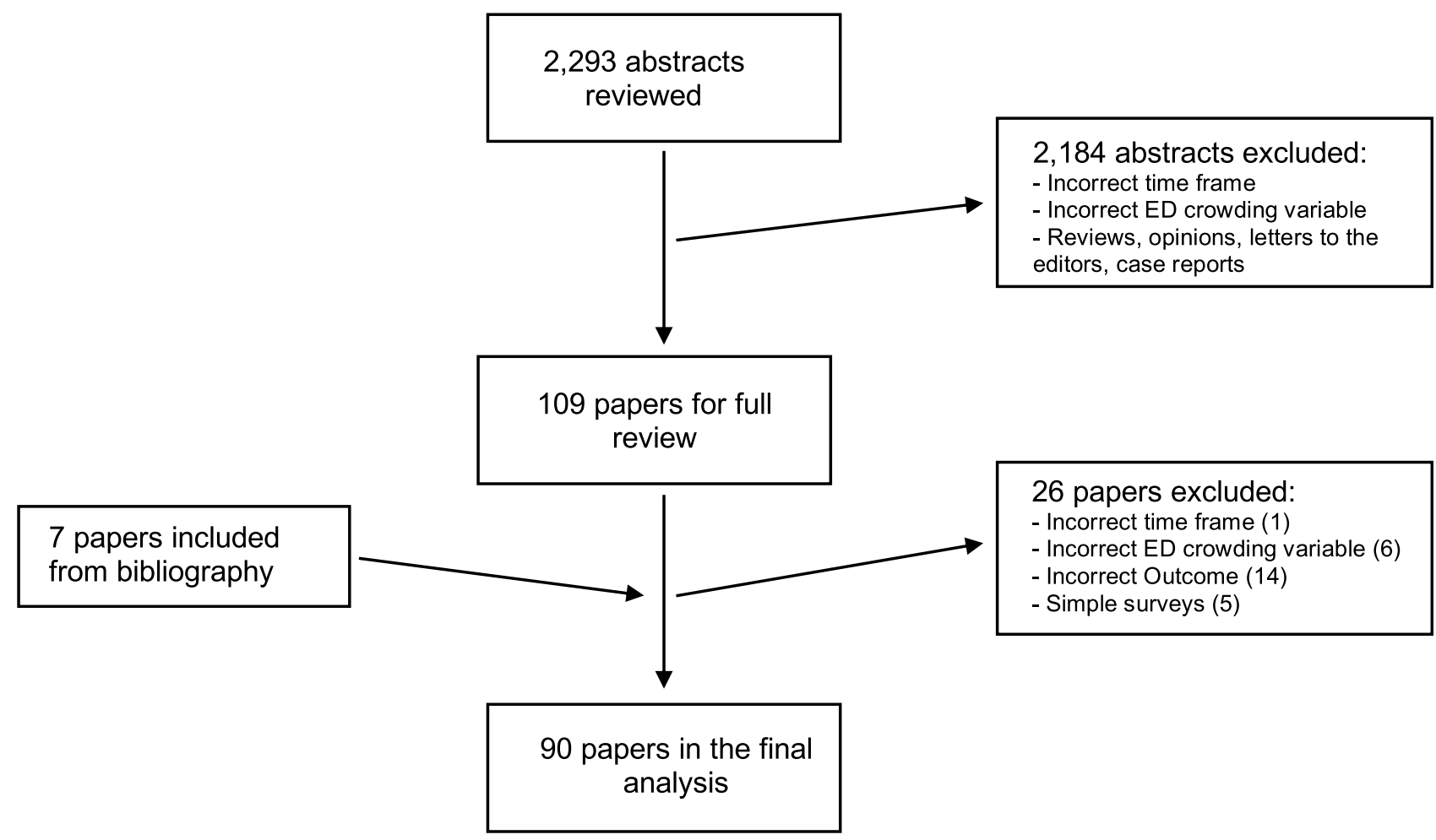

Figure I This figure summarizes the method used to select the studies of the review. Out of 2293 abstracts and titles reviewed, 109 were selected for full review. Seven more studies were later induced, and 26 later excluded, yielding a final number of 90 studies. 
a brief description of the findings, as well as the grading of the reviewers.

\section{Analysis by ED Crowding Measure}

The grouping of the papers based on the crowding measure studied (Table 1) showed that ED occupancy was the most studied measure (35 studies), followed by ED LOS (24 studies) and ED volume (21 studies). Studies about these measures were performed in community, tertiary hospitals, or both. They included adult and pediatric patients, as well as a multitude of diagnoses. The crowding measures that were the most heterogeneous were the boarding time and the number of boarders because patients were defined as boarders at different time points. Waiting room occupancy and boarding occupancy were eliminated due to a lack of studies.

In Table 2, we summarize findings from each crowding measure. Most of the variables were easy to calculate and easy to communicate, except for NEDOCS and EDWIN.

\section{Outcome Measures}

Quality of care was the most studied outcome. The EDWIN and NEDOCS had no studies with the outcome mortality. ED crowding was often associated with worse outcomes: higher mortality, worse quality of care, and worse perception of care in, respectively, 45, 75, and $100 \%$ of the studies. All the studies using the EDWIN score showed an association between increased crowding and worse outcomes. Table 2 provides a high-level summary and allows for at a glance comparison of the measures' ease of calculation, ease of communication, and definition heterogeneity. It quantifies the number of studies per measure and outcome and the number of studies that showed worse outcomes. The supplementary offers a deeper, more detailed dive into the outcomes studied. In the Supplementary Table 2, we describe the outcomes used in the 90 studies. We group them by measure and broad outcome category and clearly separate the studies that showed a positive association from those that did not.

\section{Discussion}

This review confirms the challenging aspect of measuring and defining ED crowding. The different ED crowding measures vary in the degree to which they were studied, the addressed outcomes, and the homogeneity of their definition. One should consider these factors if trying to choose one measure over another. Measures such as the ED occupancy, ED LOS, and ED volume are homogenous in their definition, well studied, easy to understand, measure and communicate and remain the obvious measure to which to go. The remaining measures are less studied. The two scores, EDWIN and NEDOCS, are very complex formulas. The advent and implementation of electronic medical records have eased the obtention of these scores with their ability to update the many required variables for the calculation constantly. The resulting score may still not be as easy to communicate to other health care providers and administrators who are not familiar with these two scores.

The studies reviewed had some variability in the definition of crowding measures, but the heterogeneity of the number of boarders and boarding time measures was higher comparably. Some standardization in the definition of boarding would be a helpful step given how valuable the measures of ED boarding are for a hospital system and how much boarding is a cause of patient dissatisfaction.

Unlike quality of care, mortality is not a widely studied outcome across the different measures. The mortality outcome is mainly studied with ED occupancy, and we would recommend this measure when addressing the outcome mortality. Note that mortality has been studied with neither the NEDOCS nor the EDWIN scores.

The perception of care, or how "busy or overwhelmed" the provider felt secondary to ED overcrowding, was less studied than the quality of care and mortality outcomes. The NEDOCS is the most studied measure on the perception of care. By nature, perception of care is more subjective than traditional outcomes. Yet, this perception of care is a more practical outcome that offers the "feel" of the providers working in a busy ED. Although difficult to quantify, this "feel" embodies a complex amalgam of the providers' engagement, the acuity of patients, surges in volume, resource-intensive patients, and the help of ancillary services. The perception of care is even more crucial to study given the physicians, advanced practice providers, and nurses burnout epidemic. The vast majority of studies using NEDOCS and EDWIN found a positive association with perception of care.

This study has multiple limitations. As shown above, the ED crowding literature is quite large, though most of the studies were performed in US tertiary care hospitals. Extrapolating results to different countries and community hospitals requires caution. ED crowding research is limited by the retrospective nature of the studies done so far. Past research has not portrayed the dynamic and rapidly changing nature of ED crowding. For example, a hypothetical 
Table I Description of Crowding Measures

\begin{tabular}{|c|c|c|c|c|c|c|}
\hline Measure, Years of Publication & Type of Hospital & Type of Diagnoses & $\begin{array}{l}\text { Type of Patients or } \\
\text { Subjects }\end{array}$ & Description of Variable & Type of studies & $\begin{array}{l}\text { Quality } \\
\text { of } \\
\text { Studies }\end{array}$ \\
\hline ED occupancy $2006-2019^{5-38}$ & $\begin{array}{l}\text { Tertiary, } 5,8-10,13-15,17,19,20,24- \\
34,36,37,39 \\
\text { Community } \\
\text { Both }^{6,7,11,16,18,21,23,38,40}\end{array}$ & 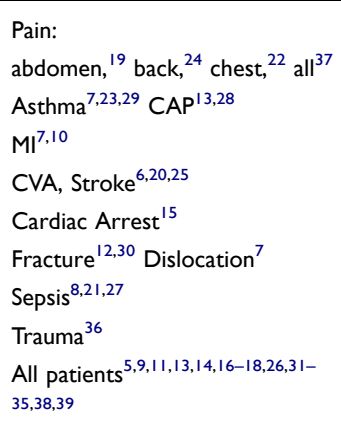 & $\begin{array}{l}\text { Adults, } 60,12,13,15,17- \\
20,22-25,27,28,31,33,35-38 \\
\text { Pediatrics }{ }^{29,30} \\
\text { All patient } \\
9,11,16,21,26,32,34 \\
\text { ED physicians and } \\
\text { nurses }^{14} \\
\text { ED Nurses }^{39}\end{array}$ & $\begin{array}{l}\text { Quartiles }^{5-8,19,22-26,33,37} \\
\text { Continuous } \\
30,12,12,13,15,16,46,18,20,21,27- \\
\text { Intervals of I hours } \\
\text { Nurse and physician survey } \\
\text { Overcrowding hazard Scale }{ }^{31}\end{array}$ & $\begin{array}{l}\text { Retrospective }^{5-9,12,13,17-19,21-} \\
30,32,33,36-38 \\
\text { Prospective } \\
\text { Survey } 10,11,15,20,34,35,42\end{array}$ & $\begin{array}{l}31 \text { Good } \\
4 \text { Fair }\end{array}$ \\
\hline $\begin{array}{l}\text { ED LOS } 2003-2019^{5,6,8,8,9,12,19,22-} \\
24,38,40,42-53\end{array}$ & $\begin{array}{l}\text { Tertiary } 5,8,9,12,19,22,43,45,48,50,53,54 \\
\text { Community } \\
\text { Both } \\
6,23,24,38,40,42,44,46,47,49,52\end{array}$ & $\begin{array}{l}\text { Pain: abdominal pain, }{ }^{19} \text { back } \\
\text { Pain, }{ }^{24} \text { chest }^{22} \\
\text { Asthma } \\
\text { MI }^{23} \text { CAP }^{40,52} \\
\text { CVA, Stroke }^{6,43,44} \\
\text { Intubated Trauma patients } \\
{ }^{45} \\
\text { Sepsis } \\
\text { Hip Fracture } \\
\text { All Patients } \\
5,9,98,40,42,47-49,51\end{array}$ & $\begin{array}{l}\text { Adults }{ }^{6,7, \mid 12,19,22-24,38,43-} \\
46,52,53 \\
\text { All patients } \\
8,9,40,42,47-51\end{array}$ & $\begin{array}{l}<\text { or }>8 \text { hours } \text { h3 }^{43} \\
\text { Quartiles,8,19,22-24,48,52 } \\
<4,4-8,>8 \text { hours }^{46} \\
<2, \geq 8 \text { hours and by hours in } \\
\text { between } \\
\text { Continuous: } \\
\text { minutes, }^{45} \text { hours } \\
>1,12,38,40,47,50,51 \\
<9,9-24,>24 \text { hours }^{42} \\
\text { hrs }^{49}\end{array}$ & $\begin{array}{l}\text { Retrospective } e^{5,6,8,9,12,19,22-24,38,40,42-} \\
53\end{array}$ & $\begin{array}{l}22 \text { Good } \\
2 \text { Fair }\end{array}$ \\
\hline $\begin{array}{l}\text { ED volume } 1999-2019^{9,21,40-} \\
42,44,50,54-67\end{array}$ & $\begin{array}{l}\text { Tertiary } 9,41,50,54-67 \\
\text { Both }^{21,40,42,44}\end{array}$ & $\begin{array}{l}\text { Asthma }^{59} \text { CAP, } \\
\text { pneumonia }^{50,56,57,67} \\
\text { CVA, TIA, stroke } \\
\text { Cardiac arrest } \\
\text { Pl } \text { MI }^{50} \\
\text { Pain }^{54,60,62} \\
\text { Sepsis }^{21} \\
\text { All patients } \\
9,41,42,55,61,65,66\end{array}$ & $\begin{array}{l}\text { Adults }{ }^{41,44,54,56-} \\
58,60,63,67 \\
\text { Pediatrics } \\
\text { All } \\
\text { patients } 92,61,40,40,42,50,55,61 \\
\text { Physicians and } \\
\text { nurses }^{64,65}\end{array}$ & $\begin{array}{l}\text { Daily, }{ }^{9,40,41,58} \text { weekly, }{ }^{61} \text { annual }{ }^{44,55,59} \\
\text { volume. } \\
\text { ED volume when patient } \\
\text { arrives }^{21,42,54,56,57,60,62,63} \\
\text { Quartiles }^{67} \\
\text { Continuous }^{50}\end{array}$ & $\begin{array}{l}\text { Retrospective }{ }^{9,21,40-42,44,50,54,56-} \\
59,61-63,67 \\
\text { Prospective } \\
\text { Survey }{ }^{54,65}\end{array}$ & $\begin{array}{l}19 \text { Good } \\
2 \text { Fair }\end{array}$ \\
\hline $\begin{array}{l}\text { Boarding time 1999- } \\
2018^{22,38,50,51,55,65,67-78}\end{array}$ & $\begin{array}{l}\text { Tertiary } 22,50,55,65,67-78 \\
\text { Both }^{38} \\
\text { Community }\end{array}$ & $\begin{array}{l}\text { Cellulitis }^{72} \\
\text { CAP, } \\
\text { pneumonia }^{50,67} \text { Pneumonia }^{72} \\
\text { Critically-ill }^{68,70} \\
\text { Chest pain } \\
\text { MI }^{50} \\
\text { Necrotizing Fasciitis. }^{71} \\
\text { All patients } \\
38,51,55,65,69,73-77\end{array}$ & $\begin{array}{l}\text { Adults } 22,67,71,72,74,76-78 \\
\text { All } \\
\text { patients } 38,50,51,55,65,68- \\
70,73,75 \\
\text { Physicians and nurses }{ }^{65}\end{array}$ & $\begin{array}{l}\text { Boarding hours }{ }^{38,50,51,69,72,74,77} \\
<6,6-24,>24 \text { hours }^{68,70} \\
\leq 3,>3 \text { hours }^{78}>8 \text { hrs }^{71} \\
\text { Annual }^{55} \\
\text { Quartiles }^{22,67} \\
\text { Mean boarding time, beginning } \\
\text { 8-hour interval }\end{array}$ & $\begin{array}{l}\text { Retrospective } 22,38,50,51,67-73,76,77 \\
\text { Prospective }^{55,75,78} \\
\text { Survey }^{65}\end{array}$ & $\begin{array}{l}14 \text { Good } \\
3 \text { Fair }\end{array}$ \\
\hline
\end{tabular}


Table I (Continued).

\begin{tabular}{|c|c|c|c|c|c|c|}
\hline Measure, Years of Publication & Type of Hospital & Type of Diagnoses & $\begin{array}{l}\text { Type of Patients or } \\
\text { Subjects }\end{array}$ & Description of Variable & Type of studies & $\begin{array}{l}\text { Quality } \\
\text { of } \\
\text { Studies }\end{array}$ \\
\hline $\begin{array}{l}\text { Number of Boarders 1999- } \\
2019^{6,8,21-24,54,57,60,64,65,69,75,79-82}\end{array}$ & $\begin{array}{l}\text { Tertiary }{ }^{8,22,54,57,60,64,65,69,75,79-} \\
81 \\
\text { Both }^{6,21,23,24,82}\end{array}$ & $\begin{array}{l}\text { Asthma }^{23} \text { CAP, pneumonia } \\
\text { Pain: back, }{ }^{24} \text { chest, }^{22} \text { all }^{54,60} \\
\text { CVA, stroke } \\
\text { Critically ill } \\
\text { Femoral } \text { Sepsis }^{8,21} \\
\text { All patients }{ }^{64,65,69,75,79,80}\end{array}$ & $\begin{array}{l}\text { Adults } \\
\text { All } \\
\text { patients } \\
\text { 8,21, } 24,64,65,69,57,60,75,79,80 \\
\text { Physicians and } \\
\text { nurses. } \\
64,65,80\end{array}$ & $\begin{array}{l}\text { Quartiles }^{6,8,22-24,54,81} \\
>4 \text { hours, }{ }^{79}>6 \text { hours }^{82} \\
\text { Number on arrival } \\
\text { Average number of boarders, } \\
\text { beginning } 8 \text {-hour interval }^{75}\end{array}$ & $\begin{array}{l}\text { Retrospective. } \\
\text { Prospective }^{65} \\
\text { Survey }^{64,65,80}\end{array}$ & $\begin{array}{l}13 \text { Good } \\
3 \text { Fair }\end{array}$ \\
\hline $\begin{array}{l}\text { ED waiting room census } 2002- \\
2017^{6,8,9,18,19,22-24,37,60,64-67,80}\end{array}$ & $\begin{array}{l}\text { Tertiary } 8,9,19,22,37,60,64-67,80 \\
\text { Both }\end{array}$ & $\begin{array}{l}\text { Asthma. }{ }^{23} \text { CAP }^{67} \\
\text { Pain: back. }{ }^{24} \text { chest }^{22} \text { all } \\
\text { CVA, stroke } \\
\text { Sepsis } \\
\text { All patients } \\
\text { 9, 18,64-66,80 }\end{array}$ & $\begin{array}{l}\text { Adults } \\
24,37,60,67,80 \\
\text { All patients } \\
\text { Physicians and nurses } \\
64- \\
66,80\end{array}$ & $\begin{array}{l}\text { Quartiles }^{6,8,19,22-24,37,50,67} \\
\text { Continuous } \\
\text { Hourly Average }\end{array}$ & $\begin{array}{l}\text { Retrospective }{ }^{6,8,9,18,19,22-24,37,67} \\
\text { Prospective }^{60} \\
\text { Survey }^{64-66,80}\end{array}$ & $\begin{array}{l}13 \text { Good } \\
2 \text { Fair }\end{array}$ \\
\hline $\begin{array}{l}\text { NEDOCS 2005-2018 } \\
11,14,34,39,66,83-91\end{array}$ & $\begin{array}{l}\text { Tertiary } 11,14,34,39,66,83-85,88-91 \\
\text { Community } 86,87\end{array}$ & All Patients ${ }^{11, \mid 4,34,39,66,83-91}$ & $\begin{array}{l}\text { Physicians and } \\
\text { nurses }{ }^{14,66,83,84,86,87,89} \\
\text { All patients }^{11,34,85,88-91} \\
\text { Pediatric }^{66} \\
\text { ED Nurses }^{39}\end{array}$ & $\begin{array}{l}\text { Quartile }{ }^{14,39,84,87,90} \\
\text { NEDOCS q10 min, AUC to predict } \\
\text { ED diversion } 11,85 \\
<100,100-140,>140^{34,91}\end{array}$ & $\begin{array}{l}\text { Retrospective }^{85} \\
\text { Prospective. }^{11,34,66,87-91} \\
\text { Survey } \\
1,39,83,84,87,89\end{array}$ & $\begin{array}{l}13 \text { Good } \\
\text { I Fair }\end{array}$ \\
\hline $\begin{array}{l}\text { EDWIN 2003- } \\
2019^{7,11,14,16,21,34,85,89,92-94}\end{array}$ & $\begin{array}{l}\text { Tertiary } \\
\text { Both }^{7,21}\end{array}$ & $\begin{array}{l}\text { Asthma }^{7} \\
\text { Dislocation }^{7} \\
\text { MI }^{7} \text { STEMI } \\
\text { All patients }^{11,14,16,21,34,85,89,92,93}\end{array}$ & $\begin{array}{l}\text { Adults }^{94} \\
\text { All } \\
\text { patients } \\
\text { Physicians and } \\
\text { nurses }^{14,92}\end{array}$ & $\begin{array}{l}\text { Quartiles }^{7} \\
<1.5>1.5^{14,93,94} \\
\text { Continuous } \\
\text { q } 10 \text { min, AUC for ED diversion } \\
11,85\end{array}$ & $\begin{array}{l}\text { Retrospective }^{7,21} 1,85,94 \\
\text { Prospective }^{11,16,34,89,93} \text { Survey }{ }^{14,89,92}\end{array}$ & $\begin{array}{l}10 \text { Good } \\
\text { I Fair }\end{array}$ \\
\hline
\end{tabular}

Notes: The measures are listed from the most to the least studied. The table provides details on the type of hospital, patients, or subjects in the studies. We provide a brief description of the variables used to measure crowding and aggregate the reviewers' ratings per measure.

Abbreviations: CAP, community-acquired pneumonia; CVA, cerebrovascular accident; TIA, transient ischemic attack; MI, myocardial infarction. 
Table 2 Summary of Findings on ED Crowding Measures

\begin{tabular}{|c|c|c|c|c|c|c|c|}
\hline \multirow{2}{*}{$\begin{array}{l}\text { Measure } \\
\text { of } \\
\text { Crowding }\end{array}$} & \multirow[t]{2}{*}{$\begin{array}{l}\text { Ease of } \\
\text { Calculation }\end{array}$} & \multirow[t]{2}{*}{$\begin{array}{l}\text { Ease of } \\
\text { Communication }\end{array}$} & \multirow{2}{*}{$\begin{array}{l}\text { Heterogeneity of } \\
\text { Measure } \\
\text { Definition }\end{array}$} & \multicolumn{4}{|c|}{$\begin{array}{l}\text { Number of Studies per Outcome, Number of Studies with } \\
\text { a Positive Association in Parentheses }\end{array}$} \\
\hline & & & & $\begin{array}{l}\text { All Outcomes, } \\
\text { with Authors } \\
\text { Ratings }\end{array}$ & $\begin{array}{l}\text { Outcome: } \\
\text { Mortality }\end{array}$ & $\begin{array}{l}\text { Outcome: } \\
\text { Quality of } \\
\text { Care }\end{array}$ & $\begin{array}{l}\text { Outcome: } \\
\text { Perception of } \\
\text { Care }\end{array}$ \\
\hline $\begin{array}{l}\text { ED } \\
\text { occupancy }\end{array}$ & $\begin{array}{l}\text { Easy } \\
\text { calculation }\end{array}$ & Self-explanatory & Low & $35 ; 3 I G, 4 F$ & $12(5)$ & $26(15)$ & $2(2)$ \\
\hline ED LOS & $\begin{array}{l}\text { Easy } \\
\text { calculation }\end{array}$ & Self-explanatory & Low & $24 ; 22 \mathrm{G}, 2 \mathrm{~F}$ & $8(4)$ & $21(17)$ & 0 \\
\hline ED Volume & $\begin{array}{l}\text { Easy } \\
\text { calculation }\end{array}$ & Self-explanatory & Low & $2 \mathrm{I} ; 19 \mathrm{G}, 2 \mathrm{~F}$ & $4(2)$ & $19(17)$ & $3(3)$ \\
\hline $\begin{array}{l}\text { Boarding } \\
\text { time }\end{array}$ & $\begin{array}{l}\text { Easy } \\
\text { calculation }\end{array}$ & Self-explanatory & High & I7; I4G, 3 F & $8(5)$ & $12(7)$ & $I(I)$ \\
\hline $\begin{array}{l}\text { Number of } \\
\text { boarders }\end{array}$ & $\begin{array}{l}\text { Easy } \\
\text { calculation }\end{array}$ & Self-explanatory & High & 16; I3G, $3 \mathrm{~F}$ & $4(I)$ & $14(10)$ & $3(3)$ \\
\hline $\begin{array}{l}\text { Waiting } \\
\text { room } \\
\text { census }\end{array}$ & $\begin{array}{l}\text { Easy } \\
\text { calculation }\end{array}$ & Self-explanatory & Low & I5; I3G, $2 \mathrm{~F}$ & $2(0)$ & $10(8)$ & $4(4)$ \\
\hline NEDOCS & $\begin{array}{l}\text { Complex } \\
\text { formula }\end{array}$ & Difficult & Low & I4; I3G, I F & 0 & $7(6)$ & $8(8)$ \\
\hline EDWIN & $\begin{array}{l}\text { Complex } \\
\text { formula }\end{array}$ & Difficult & Low & II; IOG, I F & 0 & $8(8)$ & $3(3)$ \\
\hline \multicolumn{5}{|c|}{ Percentage of studies with a positive association } & $45 \%$ & $75 \%$ & $100 \%$ \\
\hline
\end{tabular}

Notes: This table provides a high-level summary of our findings. All measures are easy to calculate and communicate, except for NEDOCS and EDWIN. All measures are relatively homogenous in their definition and utilization, except for the boarding time and number of boarders. The measures are listed from the most to the least studied. The table summarizes the reviewers' ratings per measure and the number of studies with positive (worse outcome) associations.

Abbreviations: F, fair; G, good.

patient presents to an uncrowded ED. As their workup progresses, the ED becomes progressively more crowded. To what level of crowding can one reliably attribute potential adverse outcomes? Finally, our review weighed all studies that met our inclusion criteria equally even when the number of the studied patients or subjects varied considerably between them.

This paper highlights the inequalities between the different measures. If searching for the perfect measure, you will find none. Such findings have many implications on individual practicing staff and hospital systems but also at a population level. A hospital system might consider using a combination that includes at least one traditional measure, such as ED occupancy, ED LOS, or ED volume. Public health policies that decrease crowding can be challenging to write and implement without a consensus on the best evidence-based measure and the wide variability of measures amongst ED practices. Finally, additional studies are necessary to provide insight into this complex problem and compare the different measures.

\section{Conclusion}

Our systematic review of 90 studies of ED crowding highlights the variation between each measure, especially in terms of the outcome studied. The ED occupancy is the best-studied, followed by the ED LOS and ED volume. Newer scoring systems such as the NEDOCS and EDWIN have been studied less than the more traditional ones. It is essential to consider these findings when trying to answer a research question, influence clinical practice, or write policy.

\section{Disclosure}

The authors report no conflicts of interest in this work. 


\section{References}

1. American College of Emergency Physicians (ACEP). Crowding. Policy statement. Approved April 2019. Available from: https://www.acep.org/ patient-care/policy-statements/crowding/. Accessed November 18, 2021.

2. Pines JM, Griffey RT, Cone DC. What we have learned from a decade of ED crowding research. Acad Emerg Med. 2015;22 (8):985-987. doi:10.1111/acem. 12716

3. Peterson SM, Harbertson CA, Scheulen JJ, Kelen GD. Trends and characterization of academic emergency department patient visits: a five-year review. Acad Emerg Med. 2019;26(4):410-419.

4. The NIH Study Quality Assessment Tools. Available from: https:// www.nhlbi.nih.gov/health-topics/study-quality-assessment-tools. Accessed November 18, 2021.

5. Berg LM, Ehrenberg A, Florin J, Ostergren J, Discacciati A, Goransson KE. Associations between crowding and ten-day mortality among patients allocated lower triage acuity levels without need of acute hospital care on departure from the emergency department. Ann Emerg Med. 2019;74(3):345-356. doi:10.1016/j.annemergmed.2019.04.012

6. Chatterjee P, Cucchiara BL, Lazarciuc N, Shofer FS, Pines JM. Emergency department crowding and time to care in patients with acute stroke. Stroke. 2011;42(4):1074-1080. doi:10.1161/ STROKEAHA. 110.586610

7. Epstein SK, Huckins DS, Liu SW, et al. Emergency department crowding and risk of preventable medical errors. Intern Emerg Med. 2012;7(2):173-180. doi:10.1007/s11739-011-0702-8

8. Gaieski DF, Agarwal AK, Mikkelsen ME, et al. The impact of ED crowding on early interventions and mortality in patients with severe sepsis. Am J Emerg Med. 2017;35(7):953-960. doi:10.1016/j. ajem.2017.01.061

9. Han JH, Zhou C, France DJ, et al. The effect of emergency department expansion on emergency department overcrowding. Acad Emerg Med. 2007;14(4):338-343. doi:10.1197/j.aem.2006.12.005

10. Harris B, Bai JC, Kulstad EB. Crowding does not adversely affect time to percutaneous coronary intervention for acute myocardial infarction in a community emergency department. Ann Emerg Med. 2012;59(1):13-17. doi:10.1016/j.annemergmed.2011.06.545

11. Hoot NR, Zhou C, Jones I, Aronsky D. Measuring and forecasting emergency department crowding in real time. Ann Emerg Med. 2007;49(6):747-755. doi:10.1016/j.annemergmed.2007.01.017

12. Hwang U, Richardson LD, Sonuyi TO, Morrison RS. The effect of emergency department crowding on the management of pain in older adults with hip fracture. J Am Geriatr Soc. 2006;54(2):270-275. doi:10.1111/j.1532-5415.2005.00587.x

13. Jo S, Kim K, Lee JH, et al. Emergency department crowding is associated with 28-day mortality in community-acquired pneumonia patients. $J$ Infect. 2012;64(3):268-275. doi:10.1016/j.jinf.2011.12.007

14. Jones SS, Allen TL, Flottemesch TJ, Welch SJ. An independent evaluation of four quantitative emergency department crowding scales. Acad Emerg Med. 2006;13(11):1204-1211. doi:10.1197/j. aem.2006.05.021

15. Kang J, Kim J, Jo YH, et al. ED crowding and the outcomes of out-of-hospital cardiac arrest. Am J Emerg Med. 2015;33 (11):1659-1664. doi:10.1016/j.ajem.2015.08.002

16. McCarthy ML, Aronsky D, Jones ID, et al. The emergency department occupancy rate: a simple measure of emergency department crowding? Ann Emerg Med. 2008;51(1):15-24, e1-2. doi:10.1016/j. annemergmed.2007.09.003

17. McCarthy ML, Zeger SL, Ding R, et al. Crowding delays treatment and lengthens emergency department length of stay, even among high-acuity patients. Ann Emerg Med. 2009;54(4):492-503 e4. doi:10.1016/j.annemergmed.2009.03.006

18. McCusker J, Vadeboncoeur A, Levesque JF, Ciampi A, Belzile E. Increases in emergency department occupancy are associated with adverse 30-day outcomes. Acad Emerg Med. 2014;21 (10):1092-1100. doi:10.1111/acem.12480
19. Mills AM, Shofer FS, Chen EH, Hollander JE, Pines JM. The association between emergency department crowding and analgesia administration in acute abdominal pain patients. Acad Emerg Med. 2009;16(7):603-608. doi:10.1111/j.1553-2712.2009.00441.x

20. Momeni M, Vahidi E, Seyedhosseini J, Jarchi A, Naderpour Z, Saeedi M. Emergency overcrowding impact on the quality of care of patients presenting with acute stroke. Adv J Emerg Med. 2018;2 (1):e3. doi:10.22114/AJEM.v0i0.25

21. Peltan ID, Bledsoe JR, Oniki TA, et al. Emergency department crowding is associated with delayed antibiotics for sepsis. Ann Emerg Med. 2019;73(4):345-355. doi:10.1016/j. annemergmed.2018.10.007

22. Pines JM, Pollack CV Jr, Diercks DB, Chang AM, Shofer FS, Hollander JE. The association between emergency department crowding and adverse cardiovascular outcomes in patients with chest pain. Acad Emerg Med. 2009;16(7):617-625. doi:10.1111/ j.1553-2712.2009.00456.x

23. Pines JM, Prabhu A, Hilton JA, Hollander JE, Datner EM. The effect of emergency department crowding on length of stay and medication treatment times in discharged patients with acute asthma. Acad Emerg Med. 2010;17(8):834-839. doi:10.1111/j.15532712.2010.00780.x

24. Pines JM, Shofer FS, Isserman JA, Abbuhl SB, Mills AM. The effect of emergency department crowding on analgesia in patients with back pain in two hospitals. Acad Emerg Med. 2010;17(3):276-283. doi:10.1111/j.1553-2712.2009.00676.x

25. Reznek MA, Murray E, Youngren MN, Durham NT, Michael SS. Door-to-imaging time for acute stroke patients is adversely affected by emergency department crowding. Stroke. 2017;48(1):49-54. doi:10.1161/STROKEAHA.116.015131

26. Richardson DB. Increase in patient mortality at 10 days associated with emergency department overcrowding. Med J Aust. 2006;184 (5):213-216. doi:10.5694/j.1326-5377.2006.tb00204.x

27. Shin TG, Jo IJ, Choi DJ, et al. The adverse effect of emergency department crowding on compliance with the resuscitation bundle in the management of severe sepsis and septic shock. Crit Care. 2013;17(5):R224. doi:10.1186/cc13047

28. Sikka R, Mehta S, Kaucky C, Kulstad EB. ED crowding is associated with an increased time to pneumonia treatment. Am J Emerg Med. 2010;28(7):809-812. doi:10.1016/j.ajem.2009.06.023

29. Sills MR, Fairclough D, Ranade D, Kahn MG. Emergency department crowding is associated with decreased quality of care for children with acute asthma. Ann Emerg Med. 2011;57(3):191-200 e1-7. doi:10.1016/j.annemergmed.2010.08.027

30. Sills MR, Fairclough DL, Ranade D, Mitchell MS, Kahn MG. Emergency department crowding is associated with decreased quality of analgesia delivery for children with pain related to acute, isolated, long-bone fractures. Acad Emerg Med. 2011;18(12):1330-1338. doi:10.1111/j.1553-2712.2011.01136.x

31. Sprivulis PC, Da Silva JA, Jacobs IG, Frazer AR, Jelinek GA. The association between hospital overcrowding and mortality among patients admitted via Western Australian emergency departments. Med J Aust. 2006;184(5):208-212. doi:10.5694/j.1326-5377.2006. tb00203.x

32. van der Linden N, van der Linden MC, Richards JR, Derlet RW, Grootendorst DC, van den Brand CL. Effects of emergency department crowding on the delivery of timely care in an inner-city hospital in the Netherlands. Eur J Emerg Med. 2016;23(5):337-343. doi:10.1097/MEJ.0000000000000268

33. Verelst S, Wouters P, Gillet JB, Van den Berghe G. Emergency department crowding in relation to in-hospital adverse medical events: a Large Prospective Observational Cohort Study. J Emerg Med. 2015;49(6):949-961. doi:10.1016/j.jemermed.2015.05.034

34. Wang H, Ojha RP, Robinson RD, et al. Optimal measurement interval for emergency department crowding estimation tools. Ann Emerg Med. 2017;70(5):632-9 e4. doi:10.1016/j.annemergmed.2017.04.012 
35. Watts H, Nasim MU, Sweis R, Sikka R, Kulstad E. Further characterization of the influence of crowding on medication errors. J Emerg Trauma Shock. 2013;6(4):264-270. doi:10.4103/0974-2700.120370

36. Wu D, Zhou X, Ye L, Gan J, Zhang M, Griffey R. Emergency department crowding and the performance of damage control resuscitation in major trauma patients with hemorrhagic shock. Acad Emerg Med. 2015;22(8):915-921. doi:10.1111/acem.12726

37. Pines JM, Hollander JE. Emergency department crowding is associated with poor care for patients with severe pain. Ann Emerg Med. 2008;51(1):1-5. doi:10.1016/j.annemergmed.2007.07.008

38. Derose SF, Gabayan GZ, Chiu VY, Yiu SC, Sun BC. Emergency department crowding predicts admission length-of-stay but not mortality in a large health system. Med Care. 2014;52(7):602-611. doi:10.1097/MLR.0000000000000141

39. Jobe J, Donneau AF, Scholtes B, Ghuysen A. Quantifying emergency department crowding: comparison between two scores. Acta Clin Belg. 2018;73(3):207-212. doi:10.1080/17843286.2017.1410605

40. Handel DA, Pines J, Aronsky D, et al. Variations in crowding and ambulance diversion in nine emergency departments. Acad Emerg Med. 2011;18(9):941-946. doi:10.1111/j.1553-2712.2011.01149.x

41. Rathlev NK, Chessare J, Olshaker J, et al. Time series analysis of variables associated with daily mean emergency department length of stay. Ann Emerg Med. 2007;49(3):265-271. doi:10.1016/j. annemergmed.2006.11.007

42. Mataloni F, Pinnarelli L, Perucci CA, Davoli M, Fusco D. Characteristics of ED crowding in the Lazio Region (Italy) and short-term health outcomes. Intern Emerg Med. 2019;14 (1):109-117. doi:10.1007/s11739-018-1881-3

43. Akhtar N, Kamran S, Singh R, et al. Prolonged stay of stroke patients in the emergency department may lead to an increased risk of complications, poor recovery, and increased mortality. $J$ Stroke Cerebrovasc Dis. 2016;25(3):672-678. doi:10.1016/j. jstrokecerebrovasdis.2015.10.018

44. Ben-Yakov M, Kapral MK, Fang J, Li S, Vermeulen MJ, Schull MJ. The association between emergency department crowding and the disposition of patients with transient ischemic attack or minor stroke. Acad Emerg Med. 2015;22(10):1145-1154. doi:10.1111/acem.12766

45. Carr BG, Kaye AJ, Wiebe DJ, Gracias VH, Schwab CW, Reilly PM. Emergency department length of stay: a major risk factor for pneumonia in intubated blunt trauma patients. J Trauma. 2007;63(1):9-12. doi:10.1097/TA.0b013e31805d8f6b

46. Diercks DB, Roe MT, Chen AY, et al. Prolonged emergency department stays of non-ST-segment-elevation myocardial infarction patients are associated with worse adherence to the American college of cardiology/American heart association guidelines for management and increased adverse events. Ann Emerg Med. 2007;50(5):489-496. doi:10.1016/j.annemergmed.2007.03.033

47. Guttmann A, Schull MJ, Vermeulen MJ, Stukel TA. Association between waiting times and short term mortality and hospital admission after departure from emergency department: population based cohort study from Ontario, Canada. BMJ. 2011;342(jun01 1):d2983. doi:10.1136/bmj.d2983

48. Liew D, Liew D, Kennedy MP. Emergency department length of stay independently predicts excess inpatient length of stay. Med J Aust. 2003;179(10):524-526. doi:10.5694/j.1326-5377.2003.tb05676.x

49. Nippak PM, Isaac WW, Ikeda-Douglas CJ, Marion AM, VandenBroek M. Is there a relation between emergency department and inpatient lengths of stay? Can J Rural Med. 2014;19(1):12-20.

50. Pines JM, Hollander JE, Localio AR, Metlay JP. The association between emergency department crowding and hospital performance on antibiotic timing for pneumonia and percutaneous intervention for myocardial infarction. Acad Emerg Med. 2006;13(8):873-878.

51. Salehi L, Phalpher P, Valani R, et al. Emergency department boarding: a descriptive analysis and measurement of impact on outcomes. CJEM. 2018;20(6):929-937. doi:10.1017/cem.2018.18
52. Ward MJ, Baker O, Schuur JD. Association of emergency department length of stay and crowding for patients with ST-elevation myocardial infarction. West $J$ Emerg Med. 2015;16(7):1067-1072. doi:10.5811/westjem.2015.8.27908

53. Zhang Z, Bokhari F, Guo Y, Goyal H. Prolonged length of stay in the emergency department and increased risk of hospital mortality in patients with sepsis requiring ICU admission. Emerg Med J. 2019;36(2):82-87. doi:10.1136/emermed-2018-208032

54. Hwang U, Richardson L, Livote E, Harris B, Spencer N, Sean morrison R. Emergency department crowding and decreased quality of pain care. Acad Emerg Med. 2008;15(12):1248-1255. doi:10.1111/ j.1553-2712.2008.00267.x

55. Bullard MJ, Villa-Roel C, Bond K, Vester M, Holroyd BR, Rowe BH. Tracking emergency department overcrowding in a tertiary care academic institution. Healthc Q. 2009;12(3):99-106. doi:10.12927/hcq.2013.20884

56. Fee C, Weber EJ, Bacchetti P, Maak CA. Effect of emergency department crowding on pneumonia admission care components. Am J Manag Care. 2011;17(4):269-278.

57. Fee C, Weber EJ, Maak CA, Bacchetti P. Effect of emergency department crowding on time to antibiotics in patients admitted with community-acquired pneumonia. Ann Emerg Med. 2007;50 (5):501-9, 9 e1. doi:10.1016/j.annemergmed.2007.08.003

58. Hong KJ, Shin SD, Song KJ, Cha WC, Cho JS. Association between ED crowding and delay in resuscitation effort. Am J Emerg Med. 2013;31(3):509-515. doi:10.1016/j.ajem.2012.09.029

59. Jang H, Ozkaynak M, Ayer T, Sills MR. Factors associated with first medication time for children treated in the emergency department for asthma. Pediatr Emerg Care. 2018;Publish Ahead of Print. doi:10.1097/PEC.0000000000001609

60. Mills AM, Baumann BM, Chen EH, et al. The impact of crowding on time until abdominal CT interpretation in emergency department patients with acute abdominal pain. Postgrad Med. 2010;122 (1):75-81. doi:10.3810/pgm.2010.01.2101

61. Miro O, Antonio MT, Jimenez S, et al. Decreased health care quality associated with emergency department overcrowding. Eur J Emerg Med. 1999;6(2):105-107. doi:10.1097/00063110-199906000-00003

62. Shenoi R, Ma L, Syblik D, Yusuf S. Emergency department crowding and analgesic delay in pediatric sickle cell pain crises. Pediatr Emerg Care. 2011;27(10):911-917. doi:10.1097/PEC.0b013e3182 302871

63. Tsai MT, Yen YL, Su CM, et al. The influence of emergency department crowding on the efficiency of care for acute stroke patients. Int J Qual Health Care. 2016;28(6):774-778. doi:10.1093/intqhe/ mzw109

64. Weiss SJ, Arndahl J, Ernst AA, Derlet R, Richards J, Nick TG. Development of a site sampling form for evaluation of ED overcrowding. Med Sci Monit. 2002;8(8):CR549-CR553.

65. Weiss SJ, Derlet R, Arndahl J, et al. Estimating the degree of emergency department overcrowding in academic medical centers: results of the National ED Overcrowding Study (NEDOCS). Acad Emerg Med. 2004;11(1):38-50. doi:10.1111/j.1553-2712.2004. tb01369.x

66. Weiss SJ, Ernst AA, Sills MR, Quinn BJ, Johnson A, Nick TG. Development of a novel measure of overcrowding in a pediatric emergency department. Pediatr Emerg Care. 2007;23(9):641-645. doi:10.1097/PEC.0b013e31814a69e2

67. Pines JM, Localio AR, Hollander JE, et al. The impact of emergency department crowding measures on time to antibiotics for patients with community-acquired pneumonia. Ann Emerg Med. 2007;50 (5):510-516. doi:10.1016/j.annemergmed.2007.07.021

68. Al-Qahtani S, Alsultan A, Haddad S, et al. The association of duration of boarding in the emergency room and the outcome of patients admitted to the intensive care unit. BMC Emerg Med. 2017;17(1):34. doi:10.1186/s12873-017-0143-4 
69. Gilligan P, Winder S, Singh I, Gupta V, Kelly PO, Hegarty D. The Boarders in the Emergency Department (BED) study. Emerg Med J. 2008;25(5):265-269. doi:10.1136/emj.2007.048173

70. Hirschy R, Sterk E, Dobersztyn R, Rech MA. Time spent in the emergency department and outcomes in patients with severe sepsis and septic shock. Adv Emerg Nurs J. 2018;40(2):94-103. doi:10.1097/TME.0000000000000188

71. Hong YC, Chou MH, Liu EH, et al. The effect of prolonged ED stay on outcome in patients with necrotizing fasciitis. Am J Emerg Med. 2009;27(4):385-390. doi:10.1016/j.ajem.2008.03.010

72. Liu SW, Chang Y, Weissman JS, et al. An empirical assessment of boarding and quality of care: delays in care among chest pain, pneumonia, and cellulitis patients. Acad Emerg Med. 2011;18 (12):1339-1348. doi:10.1111/j.1553-2712.2011.01082.x

73. Plunkett PK, Byrne DG, Breslin T, Bennett K, Silke B. Increasing wait times predict increasing mortality for emergency medical admissions. Eur J Emerg Med. 2011;18(4):192-196. doi:10.1097/ MEJ.0b013e328344917e

74. Reznek MA, Upatising B, Kennedy SJ, Durham NT, Forster RM, Michael SS. Mortality associated with emergency department boarding exposure: are there differences between patients admitted to ICU and non-ICU settings? Med Care. 2018;56(5):436-440. doi:10.1097/ MLR.0000000000000902

75. Schull MJ, Lazier K, Vermeulen M, Mawhinney S, Morrison LJ. Emergency department contributors to ambulance diversion: a quantitative analysis. Ann Emerg Med. 2003;41(4):467-476. doi:10.1067/mem.2003.23

76. Singer AJ, Thode Jr HC Jr, Viccellio P, Pines JM. The association between length of emergency department boarding and mortality. Acad Emerg Med. 2011;18(12):1324-1329. doi:10.1111/j.15532712.2011.01236.x

77. Sri-On J, Chang Y, Curley DP, et al. Boarding is associated with higher rates of medication delays and adverse events but fewer laboratory-related delays. Am J Emerg Med. 2014;32(9):1033-1036. doi:10.1016/j.ajem.2014.06.001

78. Bayley MD, Schwartz JS, Shofer FS, et al. The financial burden of emergency department congestion and hospital crowding for chest pain patients awaiting admission. Ann Emerg Med. 2005;45 (2):110-117. doi:10.1016/j.annemergmed.2004.09.010

79. Lord K, Parwani V, Ulrich A, et al. Emergency department boarding and adverse hospitalization outcomes among patients admitted to a general medical service. Am $J$ Emerg Med. 2018;36 (7):1246-1248. doi:10.1016/j.ajem.2018.03.043

80. Pines JM, Garson C, Baxt WG, Rhodes KV, Shofer FS, Hollander JE. ED crowding is associated with variable perceptions of care compromise. Acad Emerg Med. 2007;14(12):1176-1181. doi:10.1197/j.aem.2007.06.043

81. Richardson D, McMahon KL. Emergency department access block occupancy predicts delay to surgery in patients with fractured neck of femur. Emerg Med Australas. 2009;21(4):304-308. doi:10.1111/ j.1742-6723.2009.01201.x
82. Chalfin DB, Trzeciak S, Likourezos A, Baumann BM, Dellinger RP; group D-Es. Impact of delayed transfer of critically ill patients from the emergency department to the intensive care unit. Crit Care Med. 2007;35(6):1477-1483. doi:10.1097/01.CCM.0000266585.74905.5A

83. Anneveld M, van der Linden C, Grootendorst D, Galli-Leslie M. Measuring emergency department crowding in an inner city hospital in the Netherlands. Int J Emerg Med. 2013;6(1):21. doi:10.1186/ 1865-1380-6-21

84. Garcia-Romero M, Rita-Gafaro CG, Quintero-Manzano J, Angarita AB. NEDOCS vs subjective evaluation, inverted question markIs the health personnel of the emergency department aware of its overcrowding? Colomb Med. 2017;48(2):53-57. doi:10.25100/cm.v48i2.2131

85. Hoot N, Aronsky D. An early warning system for overcrowding in the emergency department. AMIA Anпu Symp Proc. 2006;2006:339-343.

86. Raj K, Baker K, Brierley S, Murray D. National Emergency Department Overcrowding Study tool is not useful in an Australian emergency department. Emerg Med Australas. 2006;18(3):282-288. doi:10.1111/j.1742-6723.2006.00854.x

87. Van Der Linden MC, Van Loon M, Gaakeer MI, Richards JR, Derlet RW, Van Der Linden N. A different crowd, a different crowding level? The predefined thresholds of crowding scales may not be optimal for all emergency departments. Int Emerg Nurs. 2018;41:25-30. doi:10.1016/j.ienj.2018.05.004

88. Weiss SJ, Ernst AA, Derlet R, King R, Bair A, Nick TG. Relationship between the national ED overcrowding scale and the number of patients who leave without being seen in an academic ED. Am J Emerg Med. 2005;23(3):288-294. doi:10.1016/j.ajem.2005.02.034

89. Weiss SJ, Ernst AA, Nick TG. Comparison of the national emergency department overcrowding scale and the emergency department work index for quantifying emergency department crowding. Acad Emerg Med. 2006;13(5):513-518. doi:10.1197/j.aem.2005.12.009

90. Lee CC, Lee NY, Chuang MC, Chen PL, Chang CM, Ko WC. The impact of overcrowding on the bacterial contamination of blood cultures in the ED. Am J Emerg Med. 2012;30(6):839-845. doi:10.1016/j.ajem.2011.05.026

91. Wang H, Robinson RD, Bunch K, et al. The inaccuracy of determining overcrowding status by using the national ED overcrowding study tool. Am J Emerg Med. 2014;32(10):1230-1236. doi:10.1016/ j.ajem.2014.07.032

92. Bernstein SL, Verghese V, Leung W, Lunney AT, Perez I. Development and validation of a new index to measure emergency department crowding. Acad Emerg Med. 2003;10(9):938-942. doi:10.1197/S1069-6563(03)00311-7

93. Kulstad EB, Sikka R, Sweis RT, Kelley KM, Rzechula KH. ED overcrowding is associated with an increased frequency of medication errors. Am J Emerg Med. 2010;28(3):304-309. doi:10.1016/j. ajem.2008.12.014

94. Kulstad EB, Kelley KM. Overcrowding is associated with delays in percutaneous coronary intervention for acute myocardial infarction. Int J Emerg Med. 2009;2(3):149-154. doi:10.1007/s12245-0090107-x

\section{Publish your work in this journal}

The Open Access Emergency Medicine is an international, peerreviewed, open access journal publishing original research, reports, editorials, reviews and commentaries on all aspects of emergency medicine. The manuscript management system is completely online and includes a very quick and fair peer-review system, which is all easy to use. Visit http://www.dovepress.com/testimonials.php to read real quotes from published authors. 